This item was submitted to Loughborough's Research Repository by the author.

Items in Figshare are protected by copyright, with all rights reserved, unless otherwise indicated.

\title{
Pretreatment of used cooking oil for the preparation of biodiesel using heterogeneous catalysis
}

PLEASE CITE THE PUBLISHED VERSION

http://dx.doi.org/10.1007/978-3-642-28974-3_4

PUBLISHER

(C) Springer Verlag

VERSION

AM (Accepted Manuscript)

LICENCE

CC BY-NC-ND 4.0

\section{REPOSITORY RECORD}

Haigh, Kathleen F., Sumaiya Z. Abidin, Basu Saha, and Goran T. Vladisavljevic. 2012. "Pretreatment of Used Cooking Oil for the Preparation of Biodiesel Using Heterogeneous Catalysis". figshare.

https://hdl.handle.net/2134/9362. 
This item was submitted to Loughborough's Institutional Repository (https://dspace.lboro.ac.uk/) by the author and is made available under the following Creative Commons Licence conditions.

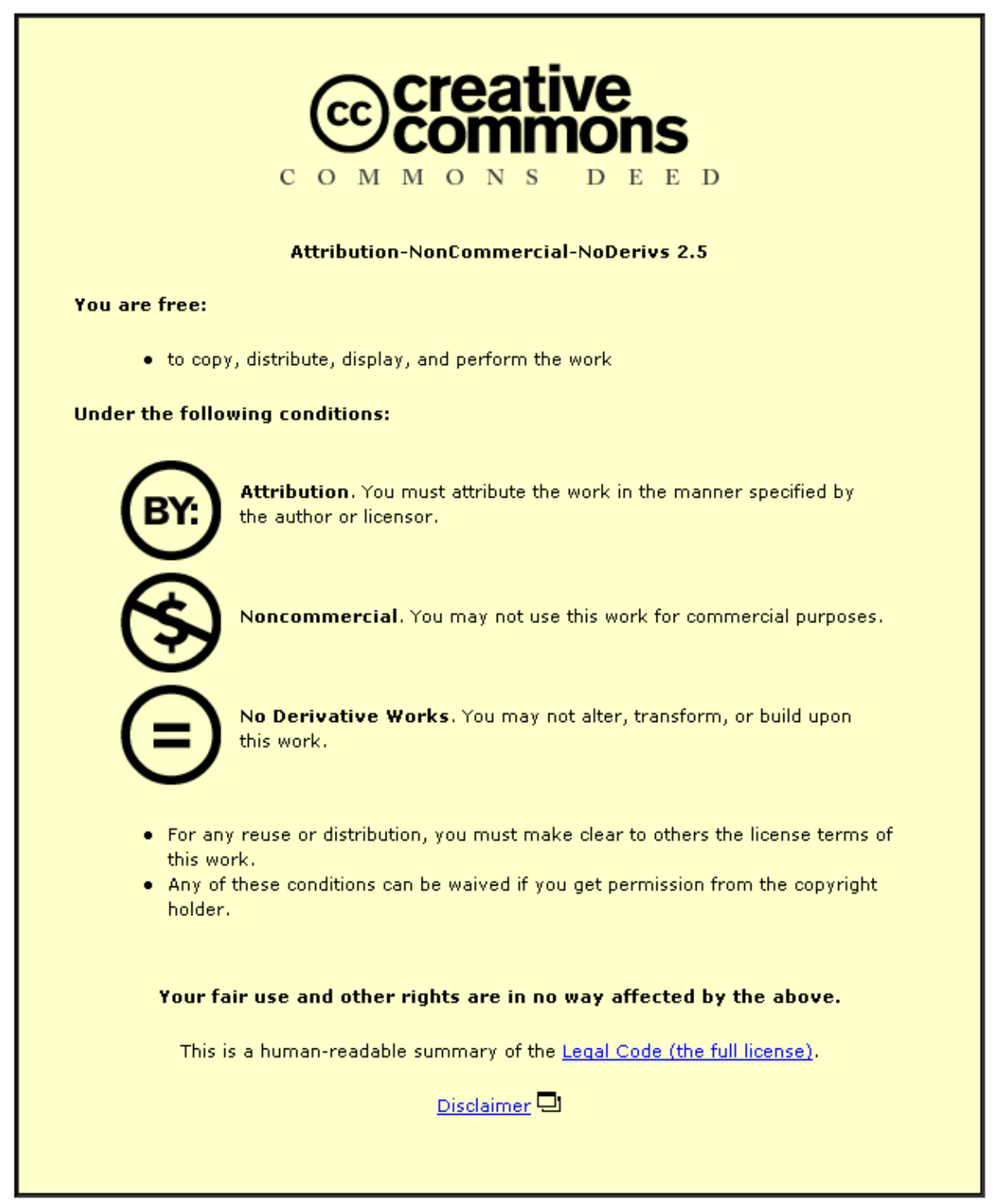

For the full text of this licence, please go to: http://creativecommons.org/licenses/by-nc-nd/2.5/ 


\title{
Pretreatment of Used Cooking Oil for the Preparation of Biodiesel using Heterogeneous Catalysis
}

\author{
Kathleen F. Haigh ${ }^{\text {a }}$ Sumaiya Z Abidin ${ }^{\text {a,b }} \cdot$ Basu Saha $^{c} \cdot$ Goran \\ Vladisavljević ${ }^{\mathrm{a}, 1}$ \\ ${ }^{a}$ Department of Chemical Engineering, Loughborough University, Leics, LE11 3TU, UK \\ ${ }^{b}$ On study leave from Faculty of Chemical and Natural Resources Engineering, Universiti \\ Malaysia Pahang, Lebuhraya Tun Razak, 26300 Gambang, Kuantan, Pahang Darul Makmur, \\ Malaysia \\ ${ }^{c}$ Department of Applied Sciences, Faculty of Engineering, Science and the Built Environment, \\ London South Bank University, London, SE1 0AA, United Kingdom
}

\begin{abstract}
Used cooking oil (UCO) offers a number of benefits for the production of biodiesel because it is a waste material and relatively cheap; however UCOs contain free fatty acids (FFAs) which need to be removed. Esterification can be used to convert the FFAs to biodiesel, and this work has compared two types of heterogeneous catalyst for esterification. An immobilized enzyme, Novozyme 435, was investigated because it has been shown to give a high conversion of FFAs and it has been compared to an ion-exchange resin, Purolite D5081, which was developed for the esterification of UCO for the production of biodiesel. It was found that a conversion of $94 \%$ was achieved using Purolite D5081 compared to 90\% conversion with Novozyme 435.
\end{abstract}

Key words Biodiesel $\cdot$ Fatty Acid Methyl Esters (FAME) $\cdot$ Esterification $\cdot$ Novozyme $435 \cdot$ Purolite D5081

\section{Introduction}

Biodiesel consists of mono-alkyl esters produced from renewable sources such as vegetable oil or animal fats. The most common process for making biodiesel is the transesterification of vegetable oils with methanol, in the presence of alkaline catalysts to form fatty acid methyl esters (FAME) which is the biodiesel product, a schematic representation of the reaction is shown in Figure 1. Vegetable oil is an expensive raw material and as a result alternatives have been investigated and these include non-edible oils such as Jatropha Curacas, by-products from oil refining such as palm fatty acid distillate, animal fats, algal oil and used cooking oil (UCO) [1-3].

\footnotetext{
${ }^{1}$ Corr. Author: Goran Vladisavljević, email: G.Vladisavljevic@lboro.ac.uk
} 


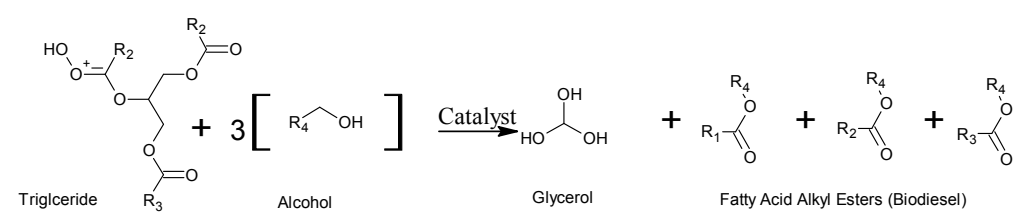

Figure 1: Schematic representation of the transesterification reaction

UCO contains free fatty acids (FFAs), which form during cooking [4] and these need to be removed prior to transesterification. Esterification can be used to convert the FFAs to biodiesel [1] and a schematic of this reaction is shown in Figure 2. Currently most esterification processes use homogeneous catalysts such as sulfuric or sulfonic acid however homogenous catalysts are difficult to separate from the reaction mixture, generate large amounts of waste water, and require expensive materials to prevent associated corrosion [5]. As a result solid acid catalysts such as ion-exchange resins have been investigated with high FFA conversions reported $[4,6]$.

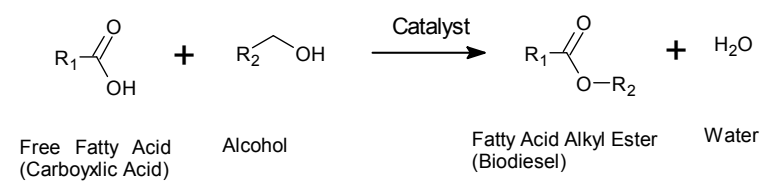

Figure 2: Schematic representation of the esterification reaction

Enzyme catalysts often result in higher reaction rates at more benign operating conditions when compared with their chemical counterparts. Novozyme 435, Candida antarctica Lipase B immobilized on acrylic resin and has been reported as an effective esterification catalyst including the esterification of FFAs to FAME [2.7]. The aim of this work is to determine if Novozyme 435 can be used to pretreat UCO which contains approximately 6 wt $\%$ FFAs and how the catalyst compares with an effective ion-exchange resin. The ionexchange resin, Purolite D5081 has been developed for the pretreatment of UCO and has been reported to give a high conversion of FFAs in UCO [6].

\section{Experimental}

Purolite D5081 was donated by Purolite International and Novozyme 435 was donated by Novozymes UK Ltd. The UCO was donated by GreenFuel Oil Co Ltd., UK and has an FFA content of approximately $6.4 \mathrm{wt} \%$. The fatty acid composition is linoleic acid (C18:2), 43\%, oleic acid (C18:1), 36\%, palmitic acid (C16:0), 13\%, stearic acid (C18:0), $3.8 \%$ and linolenic acid (C18:3), 3.6\% [6]. Solvents were purchased from Fisher Scientific UK Ltd. The esterification reactions were carried out using a jacketed batch 
reactor with a reflux condenser. All samples were analyzed for the FFA content by titration using the ASTM D974 method.

Surface area, pore volume and average pore diameter were determined from adsorption isotherms using a Micromeritics ASAP 2020 surface analyser. In order to investigate internal mass transfer limitations a portion of catalyst was separated into size fractions using a series of sieves on a Fritsch analysette shaker. The amplitude was set to 10 and the catalyst sieved for 120 min. Particle size distribution (PSD) analysis of the original catalyst and sieved fractions were carried out using a Coulter LS 130 Particle Analyzer with isopropyl alcohol as the solvent.

\section{Catalyst Characterization Data}

A summary of catalyst properties is given in Table 1 and from this data it can be seen that in terms of the particle size distribution Novozyme 435 has a larger spread of particle sizes with the average particle size smaller than Purolite D5081. While Purolite D5081 has a larger surface area than Novyzme 435 and could have a greater number of accessible catalytic sites, Novozyme 435 is more porous and has a greater pore diameter which may aid the conversion of larger molecules.

Table 1: Summary of the Catalyst Properties

\begin{tabular}{|c|c|c|}
\hline & $\begin{array}{l}\text { Immobilized Enzyme } \\
\text { Novozyme } 435\end{array}$ & $\begin{array}{l}\text { Ion-exchange resin } \\
\text { Purolite D5081 }\end{array}$ \\
\hline Nature of Catalyst & $\begin{array}{l}\text { Candida Antarctica lipase B } \\
\text { (CALB) immobilised on } \\
\text { acrylic resin }\end{array}$ & $\begin{array}{l}\text { Sulphonated polystyrene } \\
\text { cross-linked with } \\
\text { divynlbenzene }\end{array}$ \\
\hline Physical appearance & White spherical beads & Black spherical beads \\
\hline \multicolumn{3}{|l|}{ Particle size distribution $^{a}$} \\
\hline $\mathrm{d}_{10}(\mu \mathrm{m})$ & 252 & 396 \\
\hline $\mathrm{d}_{50}(\mu \mathrm{m})$ & 472 & 497 \\
\hline $\mathrm{d}_{90}(\mu \mathrm{m})$ & 687 & 639 \\
\hline BET surface area $\left(\mathrm{m}^{2} / \mathrm{g}\right)$ & 81.6 & 387 \\
\hline Total Pore Volume $\left(\mathrm{cm}^{3} / \mathrm{g}\right)$ & 0.45 & 0.39 \\
\hline Average pore diameter (nm) & 17.7 & 4.1 \\
\hline Porosity (-) & 0.349 & 0.338 \\
\hline
\end{tabular}

\section{Investigation of Internal Mass Transfer Limitations on Conversion}

Internal mass transfer resistance is due to the resistance of flow inside the particles and reducing the particle size reduces the diffusion path length and thus internal mass transfer resistance. The internal mass transfer resistance from Novozyme 435 was investigated by sieving the beads into size fractions as shown in Figure 3. The overall fraction $\left(d_{50}=472\right.$ $\mu \mathrm{m})$ represents the size distribution received from the manufacturer. 


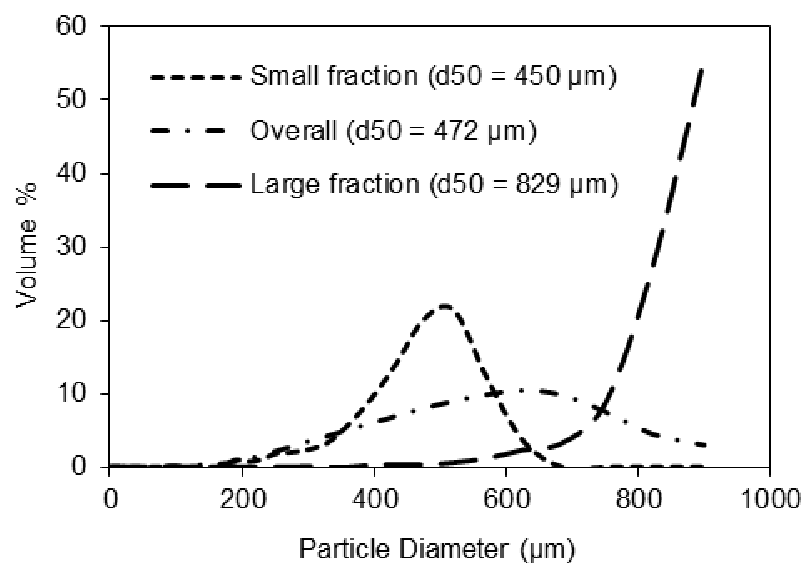

Figure 3. A comparison of the particle size distributions of Novozyme 435 used to investigate internal mass transfer limitations.

Figure 4 shows that there are intra-particle diffusion limitations when using Novozyme 435 in the size range supplied by the manufacturer.

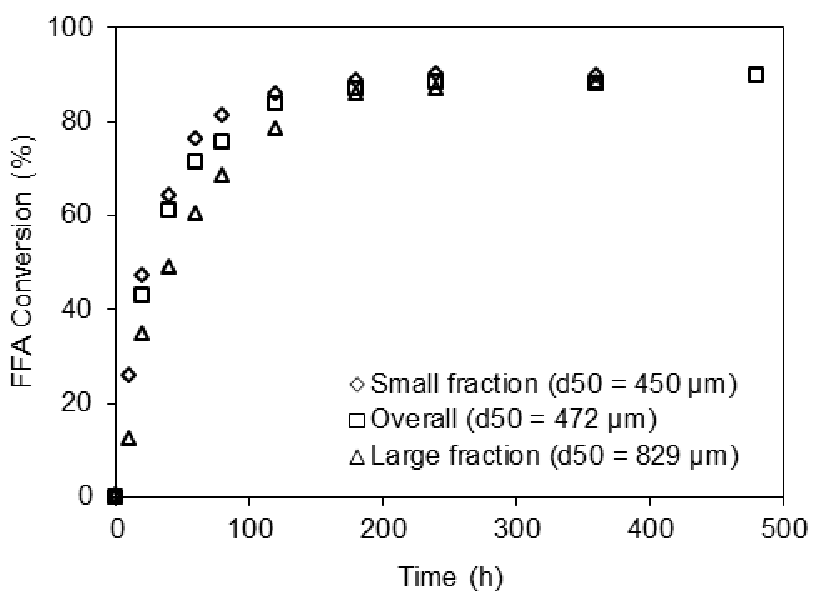

Figure 4. The effect of Particle size distribution of Novozyme 435 on conversion. The reaction conditions are temperature $=50{ }^{\circ} \mathrm{C}$, catalyst loading $=1 \mathrm{wt} \%$, mole ratio $=6.2: 1$ methanol to FFA.

Purolite D5081 was previously reported to have no internal mass transfer limitations for the typical particle size supplied by the manufacturer [6]. A sieved fraction with an average particle size $\left(\mathrm{d}_{50}\right)$ of $463 \mu \mathrm{m}$ was compared to the original particle size distribution $\left(\mathrm{d}_{50}=497 \mu \mathrm{m}\right)$.

\section{Comparison of Optimum Conditions for the two catalysts investigated}

The optimum conditions for each catalyst were identified by varying the key parameters; for Purolite D5081 these were temperature $\left(50-65{ }^{\circ} \mathrm{C}\right)$, methanol to FFAs mole ratio (mole ratio) (66-197:1) and catalyst loading (0.50-1.50 wt\%). While for Novozyme 435 
the parameters investigated were temperature $\left(30-60{ }^{\circ} \mathrm{C}\right)$, methanol to FFAs mole ratio (3.9-15.5:1) and catalyst loading (0.75-1.50 wt\%). A summary of the optimum conditions for both catalysts is given in Table 2 .

It was found that there was a large difference in the optimum mole ratios for these two catalysts. In the case of Novozyme 435 it was found that there was a narrow range of mole ratio where a high conversion was possible because Novozyme 435 is inhibited by high concentrations of methanol [2] while reducing the concentration means there is insufficient methanol for the reaction. In comparison a much larger mole ratio was required when using Purolite D5081 and the conversion decreased with decreasing mole ratio. There is an order of magnitude difference in the optimum mole ratios and comparing the catalysts at the same reaction conditions would not be meaningful. As a result conversion has been compared using the optimum conditions for each catalyst and this data is shown in Figure 5.

From this data it can be seen that with Novozyme 435 the initial reaction rate is faster however the conversion is slightly lower with Novozyme 435 reaching $90 \%$ compared to 94\% with Purolite D5081 after $600 \mathrm{~min}$ of reaction time. Novozyme 435 offers numerous benefits over Purolite D5081 because a high conversion is achieved at a much lower mole ratio, lower temperature and catalyst loading. In particular the significant reduction in methanol requirements means that for the same equipment size a much greater capacity is possible and the process will be much safer. A disadvantage is that the cost of enzymes tends to be much greater than that for ion-exchange resins.

Table 2 Comparison of the Optimum Conditions for Novozyme 435 and Purolite D5081

\begin{tabular}{lll}
\hline & Novozyme 435 & Purolite D5081 \\
\hline Methanol to FFA mole Ratio & $6.2: 1$ & $98: 1$ \\
Temperature $\left({ }^{\circ} \mathrm{C}\right)$ & 50 & 60 \\
Catalyst Loading $(\mathrm{wt} \%)$ & 1.00 & 1.25 \\
\hline
\end{tabular}




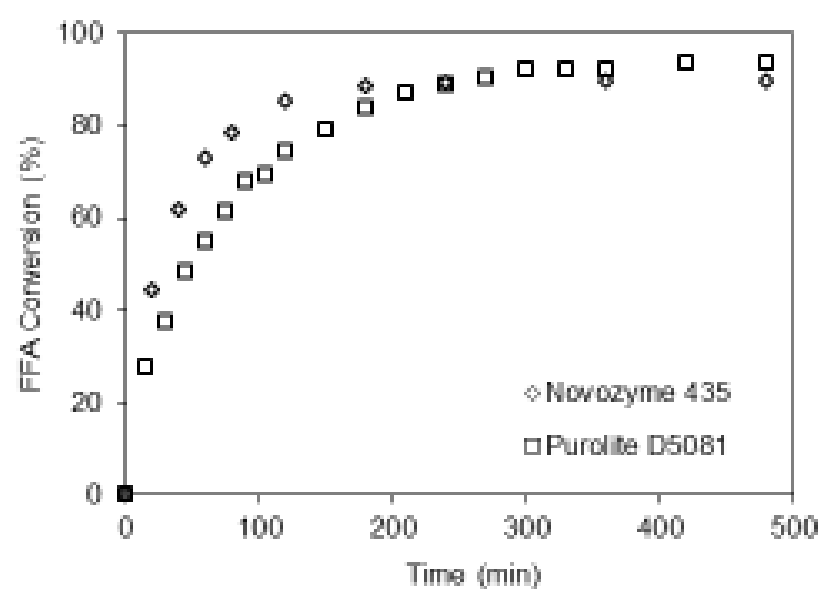

Figure 5 Comparison of conversion for Novozyme 435 and Purolite D5081 at the optimum conditions for each catalyst as specified in Table 2 .

\section{Conclusions}

The catalytic action of two types of catalyst, an ion-exchange resin, Purolite D5081 and an immobilized enzyme, Novozyme 435 were compared for the esterification pretreatment of UCO for the preparation of biodiesel. Both catalysts gave a good conversion of FFAs to biodiesel in UCO with the optimum conditions summarized in Table 2. A slightly higher conversion of $94 \%$ is possible with Purolite D5081 compared to $90 \%$ conversion of FFAs using Novozyme 435 after 600 min of reaction time. It was found that using Novozyme 435 as the catalyst resulted in a large reduction in the amount of methanol required with the optimum mole ratio going from 98:1 methanol to FFA with Purolite D5081 to a mole ratio of 6.2:1.

\section{Acknowledgement}

We thank EPSRC funding of the PhD scholarship for $\mathrm{KH}$ and Universiti Malaysia Pahang and Malaysian Government for the PhD scholarship to SZA. We would also like to thank Purolite International Ltd (Mr. Brian Windsor and the late Dr. Jim Dale) for supplying the ion-exchange catalyst and Novozymes UK. Ltd. (Dr. David Cowan) for supplying the enzyme catalyst.

\section{References}

1. C.C. Enweremadu, M.M. Mbarawa, Renew. Sust. Energ. Rev. 13, 2205-2224 (2009)

2. M.M.R. Talukder, J.C. Wu, S.K.Lau, L.C. Cui, G. Shimin, A. Lim, Energ. Fuel 23, 1-4 (2009)

3. M. Zabeti, W.M.A Wan Daud, M.K. Aroua, Fuel Process. Technol. 90, 770-777 (2009)

4. N. Ozbay, N. Oktar, N. Tapan, Fuel 87, 1789-1798, (2008) 
5. C.S.Caetano, L. Guerreiro, I.M. Fonseca, A.M. Ramos, J. Vital, J.E. Castanheiro, Appl. Catal. A-Gen. 359, 41-46 (2009)

6. S.Z. Abidin, K.F. Haigh, B. Saha, Appl. Catal. A-Gen. submitted manuscript (2011)

7. M.S. Souza, E.C.G. Aguieiras, M.A.P da Silva, M.A.P. Langone, Appl. Biochem. Biotech. 154, 74-88 (2009) 


\section{Figure legends}

Figure 1 Schematic representation of the esterification reaction

Figure 2 Schematic representation of the transesterification reaction

Figure 3 A comparison of the particle size distributions of Novozyme 435 used to investigate internal mass transfer limitations.

Figure 4 The effect of Particle size distribution of Novozyme 435 on conversion. The reaction conditions are temperature $=50^{\circ} \mathrm{C}$, catalyst loading $=1 \mathrm{wt} \%$, mole ratio $=6.2: 1$ methanol to FFA.

Figure 5 Comparison of conversion for Novozyme 435 and Purolite D5081 at the optimum conditions for each catalyst as specified in Table 2 .

\section{Table headings}

Table 1: Summary of the Catalyst Properties

Table 2: Comparison of the Optimum Conditions for Novozyme 435 and Purolite D5081 


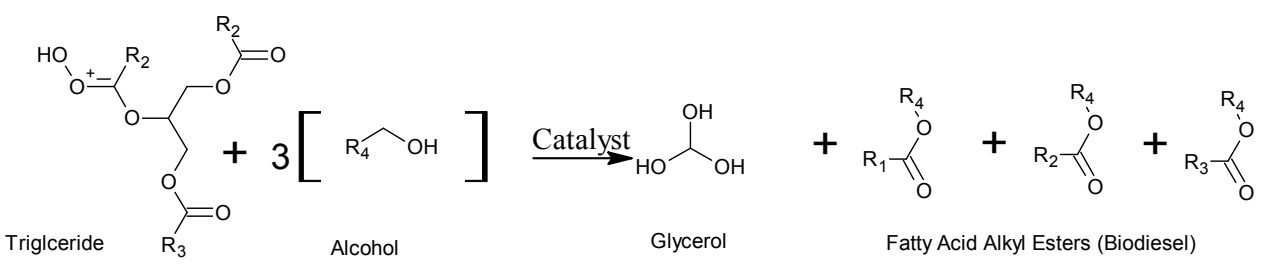

Figure 1 Schematic representation of the transesterification reaction

$$
\mathrm{R}_{1} \overbrace{\mathrm{OH}}^{\mathrm{O}}+\mathrm{R}_{2} \widehat{\mathrm{OH}}_{\mathrm{OH}}^{\text {Catalyst }} \longrightarrow \mathrm{R}_{1} \overbrace{\mathrm{O}-\mathrm{R}_{2}}^{\mathrm{O}}+\mathrm{H}_{2} \mathrm{O}
$$

Free Fatty Acid Alcohol (Carboyxlic Acid)

Fatty Acid Alkyl Ester Water (Biodiesel)

Figure 2 Schematic representation of the esterification reaction

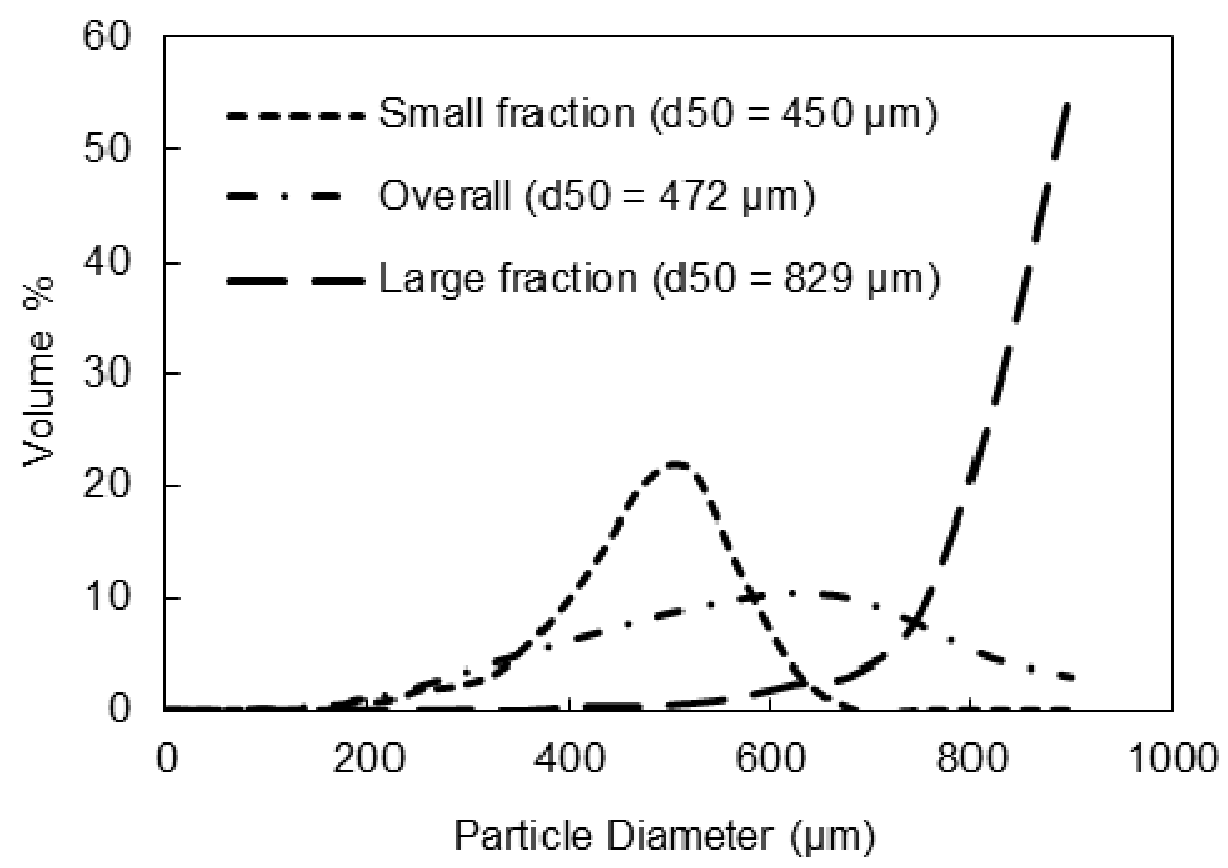

Figure 3 A comparisfon of the particle size distributions of Novozyme 435 used to investigate internal mass transfer limitations. 


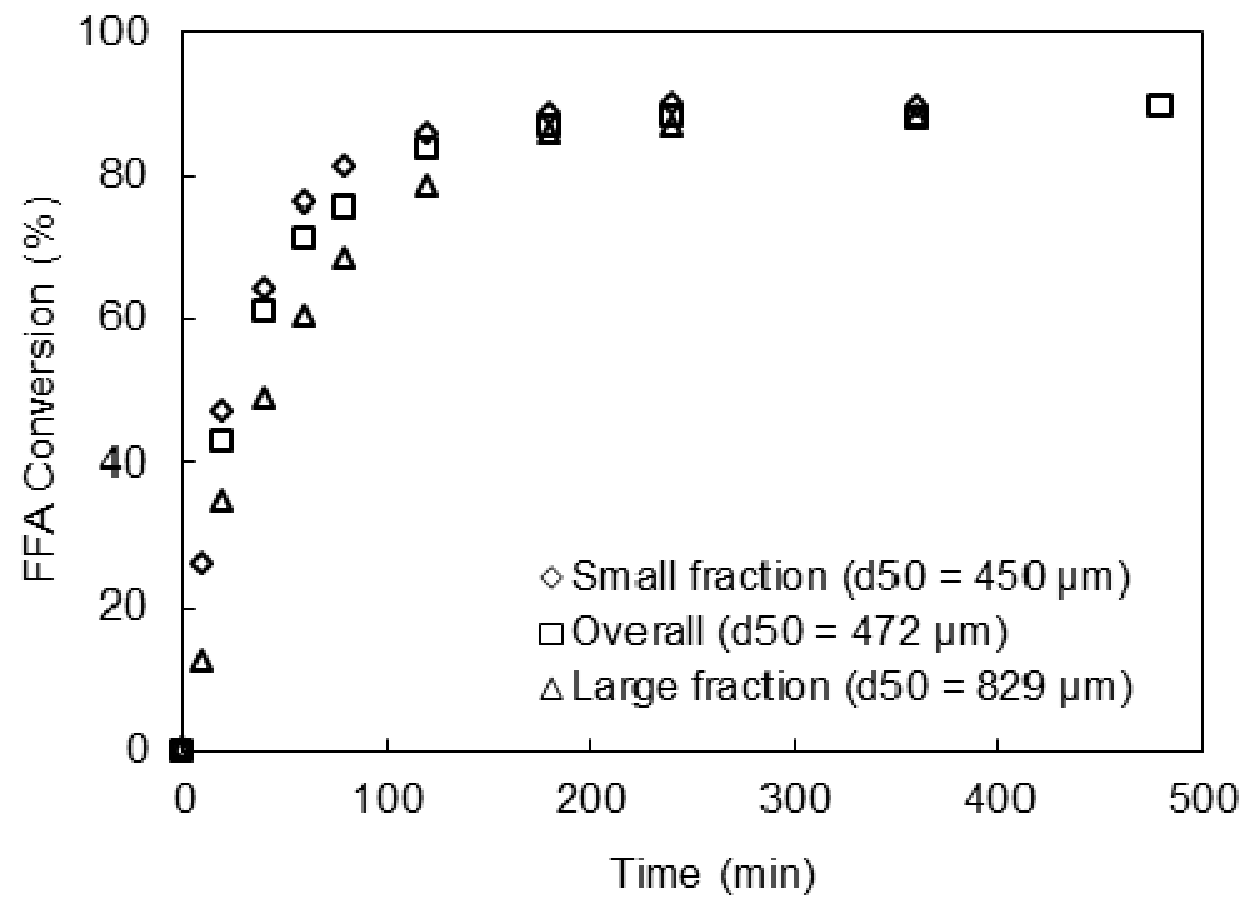

Figure 4 The effect of Particle size distribution of Novozyme 435 on conversion. The reaction conditions are temperature $=50{ }^{\circ} \mathrm{C}$, catalyst loading $=1 \mathrm{wt} \%$, mole ratio $=6.2: 1$ methanol to FFA.

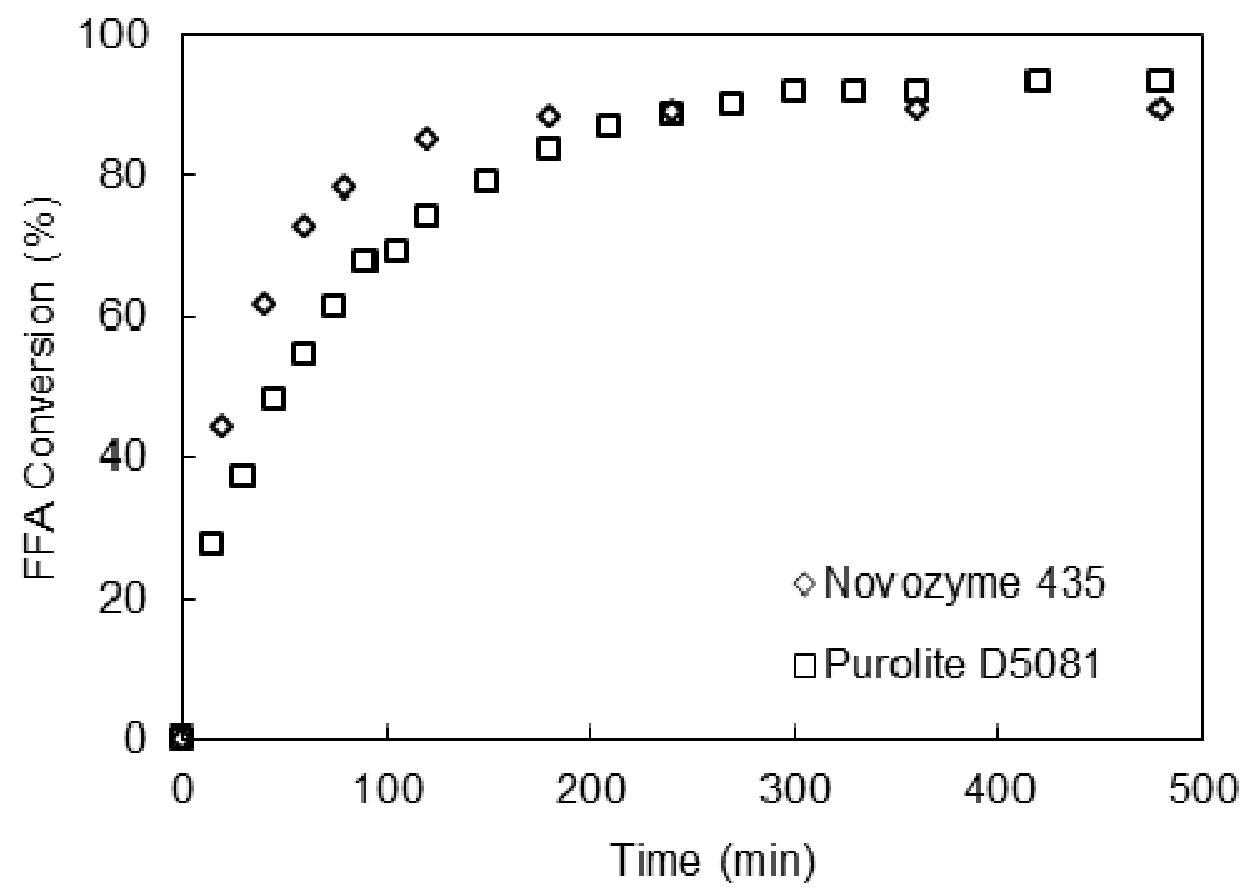

Figure 5 Comparison of conversion for Novozyme 435 and Purolite D5081 at the optimum conditions for each catalyst as specified in Table 2 . 
Table 1: Summary of the Catalyst Properties

\begin{tabular}{lll}
\hline & $\begin{array}{l}\text { Immobilized Enzyme } \\
\text { Novozyme 435 }\end{array}$ & $\begin{array}{l}\text { Ion-exchange resin } \\
\text { Purolite D5081 }\end{array}$ \\
\hline Nature of Catalyst & $\begin{array}{l}\text { Candida Antarctica lipase B } \\
\text { (CALB) immobilised on }\end{array}$ & $\begin{array}{l}\text { Sulphonated polystyrene } \\
\text { cross-linked with } \\
\text { divynlbenzene }\end{array}$ \\
& $\begin{array}{l}\text { Bcrylic resin } \\
\text { Black spherical beads }\end{array}$ \\
Physical appearance & White spherical beads & 396 \\
Particle size distribution ${ }^{\mathrm{a}}$ & & 497 \\
$\mathrm{~d}_{10}(\mu \mathrm{m})$ & 252 & 639 \\
$\mathrm{~d}_{50}(\mu \mathrm{m})$ & 472 & 387 \\
$\mathrm{~d}_{90}(\mu \mathrm{m})$ & 687 & 0.39 \\
BET surface area $\left(\mathrm{m}^{2} / \mathrm{g}\right)$ & 81.6 & 4.1 \\
Total Pore Volume $\left(\mathrm{cm}^{3} / \mathrm{g}\right)$ & 0.45 & 0.338 \\
Average pore diameter $(\mathrm{nm})$ & 17.7 & \\
Porosity $(-)$ & 0.349 & \\
\hline
\end{tabular}

${ }^{\mathrm{a}} \mathrm{d}_{\mathrm{x} 0}$ is the $\mathrm{x} 0$ volume $\%$

Table 2 Comparison of the Optimum Conditions for Novozyme 435 and Purolite D5081

\begin{tabular}{lll}
\hline & Novozyme 435 & Purolite D5081 \\
\hline Methanol to FFA mole Ratio & $6.2: 1$ & $98: 1$ \\
Temperature $\left({ }^{\circ} \mathrm{C}\right)$ & 50 & 60 \\
Catalyst Loading $(\mathrm{wt} \%)$ & 1.00 & 1.25 \\
\hline
\end{tabular}

